\title{
Influence of the environment and production components on the protein content of green cowpea grain ${ }^{1}$
}

\author{
Influência ambiental e de componentes da produção sobre o teor de proteína em grãos \\ verdes de feijão-caupi
}

\author{
Linda Brenna Ribeiro Araújo ${ }^{2 *}$, Antônio Moreira Barroso Neto², Cândida Hermínia Campos de Magalhães \\ Bertini $^{2}$, Lineker de Sousa Lopes ${ }^{2}$ and Maria Izabel Gallão ${ }^{3}$
}

\begin{abstract}
The protein content of the cowpea has proved to be very variable, especially of the green grain. The aim of this study, therefore, was to obtain information on the influence of the environment and genetic variability on the total protein content (TPC) of green cowpea grain, as well as to evaluate the effects of production components on this variable. Sixteen cowpea genotypes were evaluated in two environments (Pentecoste and Acaraú) in the state of Ceará, in a simple factorial scheme ( $16 \times 2)$ for eight production components and protein content. The grain was collected while still green (after filling was complete - stage R5) and protein quantification was carried out using the Bradford method. Path analysis was performed in order to identify possible relationships between the agronomic variables and the protein content. There was a different response from the genotypes for each environment and in the interaction between genotype and environment. In Pentecoste, the MNC00-303-09E strain was highlighted, with a TPC of 6.602\%, while in Acaraú, the Paulistinha cultivar stood out with a TPC content of $15.154 \%$. For the genotypes under evaluation, selection for total protein content should be made in Acaraú via direct selection of the green-pod-grain weight, 100-grain weight and green-pod weight, and in Pentecoste, via indirect selection of the green-pod weight and green-grain yield.
\end{abstract}

Key words - Vigna unguiculata. Green beans. Biofortification.

RESUMO - O teor de proteína em feijão-caupi tem se mostrado muito variável, especialmente para grãos verdes. Portanto, o objetivo deste trabalho foi obter informações sobre a influência do ambiente e a variabilidade genética para o teor de proteínas totais (TPT) em grãos verdes de feijão-caupi, bem como avaliar os efeitos de componentes de produção sobre essa variável. Foram avaliados dezesseis genótipos de feijão-caupi em dois ambientes (Pentecoste e Acaraú) no estado do Ceará, em esquema fatorial simples (16 x 2) para oito componentes de produção e teor de proteínas. Os grãos foram coletados verdes (após o completo enchimento - estádio R5) e a quantificação proteica foi realizada pelo método de Bradford. Realizou-se a análise de trilha a fim de identificar possíveis relações entre as variáveis agronômicas e o teor de proteínas. Verificou-se resposta diferenciada dos genótipos nos ambientes de cultivo e interação genótipos por ambientes. Para o ambiente Pentecoste, o destaque foi a linhagem MNC00-303-09E com 6,602\% de TPT e em Acaraú para a cultivar Paulistinha, com 15,154\%. A seleção para teor de proteína total dos genótipos avaliados deve ser feita em Acaraú por seleção direta dos componentes massa de grãos de vagem verde, massa de cem grãos e massa de vagem verde, e em Pentecoste por seleção indireta da massa de vagem verde e componente produtividade de grãos verdes.

Palavras-chave - Vigna unguiculata. Feijão-verde. Biofortificação.

DOI: $10.5935 / 1806-6690.20210037$

Editor-in-Chief: Profa. Ana Kelly Firmino da Silva - kelly.firmino@ufc.br

*Author for correspondence

Received for publication on 16/03/2020; approved on 28/10/2020

${ }^{1}$ Trabalho de pesquisa relativo ao Programa de melhoramento genético de feijão-caupi da Universidade Federal do Ceará (UFC) em parceria com a Embrapa Meio-Norte

2Departamento de Fitotecnia, Universidade Federal do Ceará/UFC, Fortaleza-CE, Brasil, lindabrenna@gmail.com (ORCID ID 0000-0002-3554-3908), ambnetonet@yahoo.com.br (ORCID ID 0000-0002-9777-9844), candida@ufc.br (ORCID ID 0000-0003-2949-5660), linekerlk@gmail.com (ORCID ID 0000-0002-7599-6434)

33epartamento de Biologia, Universidade Federal do Ceará/UFC, Fortaleza-CE, Brasil, edybel@ufc.br (ORCID ID 0000-0001-9299-0803) 


\section{INTRODUCTION}

The cowpea [Vigna unguiculata (L.) Walp.] contributes to nutrition and food security in various semiarid regions of the planet (DDAMULIRA et al., 2015). The species is the main source of vegetable protein in the Brazilian diet and is a basic food for low-income populations in the northeast of the country.

Several cowpea cultivars have been launched in the northeast of Brazil, the only aim being the predominance of desired agronomic characteristics, with no studies being made of their nutritional quality or protein content (SILVA; FREIRE FILHO, 1999). There is however great variation in the protein content of different cowpea genotypes (DDAMULIRA et al., 2015).

In addition, genetic control of total protein content is known to be complex. Tchiagam et al. (2011), suggest that the protein content of cowpea seed is highly variable and mainly controlled by non-additive genes. It therefore not only depends on the genes that control the synthesis and accumulation of a specific protein fraction, but also on the soil and climate conditions at the cultivation sites (REYES-MORENO; PAREDE-LÓPEZ, 1993), as well as the maturation stage of the grain. Due to an increase in their consumption as green grains, the influence of the maturation stage on the protein content must also be considered.

The effect of the genotype $\mathrm{x}$ environment interaction on the protein content of the cowpea has been quantified for dry-grain production (DA SILVA et al., 2016; GERRANO et al., 2018; WENG et al., 2019). However, few contemplate understanding this interaction on green-grain production and on the total protein content of the grain. The aim of this study, therefore, was to obtain information on genetic variability and on the influence of the environment on the total protein content of green cowpea grain, as well as to evaluate the effects of production components on this characteristic in order to make indirect selection possible.

\section{MATERIAL AND METHODS}

The trials were conducted in two districts in the state of Ceará, Brazil, both with a mildly hot tropical semi-arid climate (INSTITUTO DE PESQUISA E ESTRATÉGIA ECONÔMICA DO CEARÁ, 2020). The environments were: 1) Pentecoste (034' S, 39¹6'13"' $\mathrm{W}, 45 \mathrm{~m})$, where cultivation took place during the second half of 2012; and 2) Acaraú (0304' S, 4004'02”'W, $16.5 \mathrm{~m}$ ), with cultivation during the first half of 2013.

The experimental material comprised sixteen cowpea genotypes, selected during the preliminary trial of the Embrapa
Meio-Norte cowpea breeding program. The design was of randomised blocks with four replications. Each experimental plot was $5.0 \mathrm{~m} \times 3.2 \mathrm{~m}$ in size and consisted of four rows of plants. The two central rows were considered the working plot. Sowing was carried out manually, with a spacing of $0.2 \mathrm{~m}$ between plants and $0.8 \mathrm{~m}$ between rows.

The plants were thinned out 15 days after sowing, leaving two plants per hole and maintaining a field population of 100,000 plants $\mathrm{ha}^{-1}$. Irrigation was by micro-sprinkler in Pentecoste, and sprinkler in Acaraú, with weekly irrigation depths, based on soil retention and crop requirement, of $87 \mathrm{~mm}$ and $50.7 \mathrm{~mm}$ respectively throughout the experiment. During cultivation, the rainfall in Acaraú was $366.6 \mathrm{~mm}$, while in Pentecoste there was no rainfall (CEARENSE METEOROLOGY AND WATER RESOURCES FOUNDATION, 2020).

Fertilisation was based on the chemical analysis of the soil, as recommended for the crop (CRAVO; VIEGAS; BRASIL, 2007). Potassium chloride (66.7 $\left.\mathrm{kg} \mathrm{ha}^{-1}\right)$ and single superphosphate $\left(388.9 \mathrm{~kg} \mathrm{ha}^{-1}\right)$ were applied in both environments when planting. Fifteen days after sowing, a top-dressing of urea $\left(43.5 \mathrm{~kg} \mathrm{ha}^{-1}\right)$ was applied.

Harvesting was carried out when the grain showed $60 \%$ to $70 \%$ moisture, as per the methodology suggested by Freire Filho et al. (2005), following the maturation pattern of each genotype.

The production component data were obtained for each environment, and included green-pod length (GPL), green-pod weight (GPW), green-pod-grain weight (GPGW), number of green-pod grains (NGPG), 100green-grain weight $(100 \mathrm{GW})$, green grain index (GGI) (equal to the quotient of the grain weight of five green pods and the total weight of the five pods, times 100), Green-pod yield (GPY), green-grain yield (GGY) and total protein content (TPC).

\section{Determining the grain protein content}

The green grains were freeze-dried to remove the moisture. Four 0.1-g samples of grain flour, obtained by grinding in a mortar, were then removed for each genotype. The materials were weighed and left for 12 hours for lipid extraction with the addition of $1 \mathrm{~mL}$ hexane. The following day, the samples were centrifuged at $7826 \mathrm{G}$ for 4 minutes, and the supernatant removed and discarded.

The samples $(0.1 \mathrm{~g}$ per $2-\mathrm{ml}$ microtube $)$ were left to react with $1 \mathrm{ml} 0.1 \mathrm{M} \mathrm{NaOH}$ for 20 minutes, with the supernatant removed by centrifuging at $7826 \mathrm{G}$ for 4 minutes. This operation was carried out twice for each sample until the protein was exhausted. The supernatant was reserved for protein quantification in a microplate spectrophotometer, as per the method proposed by Bradford (1976). 


\section{Data analysis}

The assumptions of the analysis of variance, which was carried out for a randomised block design (RBD) with four replications in a simple 2 x 16 factorial scheme, were verified. The first factor comprised the two environments and the second factor, the sixteen genotypes under evaluation. The effects were considered fixed for the genotypes, blocks, environments and genotype $\mathrm{x}$ environment interaction. After verifying the significance level using the F-test, the mean values were compared by Scott-Knott test at 5\% probability.

The path analysis was carried out as per Li (1975), to determine the direct and indirect effects of the production components on the protein content of the green grain. This analysis was based on the estimation of the genetic correlation coefficient matrix, where the path coefficients are generally estimated from the system of equations $\mathrm{X}^{\prime} \mathrm{X} \beta^{\wedge}=\mathrm{X}^{\prime} \mathrm{Y}$.

where:

$$
\begin{aligned}
& X^{\prime} Y=\left[\begin{array}{l}
r_{1 y} \\
r_{2 y} \\
\cdots \\
r_{n y}
\end{array}\right] \\
& X^{\prime} X=\left[\begin{array}{l}
1 \cdots r_{12} \cdots r_{1 n} \\
r_{12} \cdots 1 \cdots r_{2 n} \\
\cdots \cdots \cdots \cdots \cdots \cdots \\
r_{1 n} \cdots r_{2 n} \cdots 1
\end{array}\right] \\
& \hat{\beta}=\left[\begin{array}{l}
\rho_{1} \\
\rho_{2} \\
\cdots \\
\rho_{n}
\end{array}\right]
\end{aligned}
$$

so that:

$$
r_{i y}=\rho_{i}+\sum_{j \neq i}^{n} \rho_{j} r_{i j}
$$

where:

$\mathrm{r}_{\mathrm{iy}}$ : correlation between the main variable $(\mathrm{y})$ and the $\mathrm{i}$-th explanatory variable;

$\mathrm{p}_{\mathrm{i}}$ : measure of the direct effect of variable $\mathrm{i}$ on the main variable;

$\mathrm{p}_{\mathrm{j}} \mathrm{r}_{\mathrm{ij}}$ : measure of the indirect effect of variable $\mathrm{i}$, via variable $\mathrm{j}$, on the main variable.

In turn, the coefficient of determination of the path diagram is given by the following equation:

$$
\mathrm{R}^{2}=\mathrm{p}_{1} \mathrm{r}_{1 \mathrm{y}}+\mathrm{p}_{2} \mathrm{r}_{2 \mathrm{y}}+\ldots+\mathrm{p}_{\mathrm{n}} \mathrm{r}_{\mathrm{ny}}
$$

The residual effect was estimated by the equation:

$$
\hat{\rho}_{g}=\sqrt{1-R^{2}}
$$

The degree of multicollinearity of the $X^{\prime} X$ matrix was established based on its condition number $(\mathrm{CN})$, which is the ratio between the highest and lowest eigenvalues of the matrix (MONTGOMERY; PECK, 1981). The eigenvalues of the matrix were analysed to identify the approximate nature of the linear dependence between the characteristics, and to detect those that contributed to the appearance of multicollinearity (BELSLEY et al., 1980).

The coefficient of genetic variation was obtained from the expression:

$$
C V g(\%)=\frac{100 \sqrt[2]{V(G)}}{X}
$$

where:

$\bar{X}:$ mean value of the characteristic;

$\mathrm{V}(\mathrm{G})$ : genetic variance.

Broad-sense heritability was estimated as per the expression:

$$
h^{2}(\%)=\frac{V(G)}{V(F)} X 100
$$

where:

$\mathrm{V}(\mathrm{F})$ : phenotypic variance.

All the statistical-genetic analysis was carried out using the GENES computer software (CRUZ, 2013).

\section{RESULTS AND DISCUSSION}

According to the results of the joint analysis of variance for total protein content (TPC), there was a significant difference between genotypes $(F=0.67$; $p<0.01)$, demonstrating the existing genetic variability, and between environments $(F=143.92 ; \mathrm{p}<0.01)$. There was also significant interaction between genotype and environment $(\mathrm{GxE})(\mathrm{F}=1.83 ; \mathrm{p}<0.01)$, with these results approaching those presented by Weng et al. (2019) when working with dry grain. The authors found that there was a difference regarding protein content for different genotypes in different environments, confirming the need to evaluate environmental effects on this characteristic. The value for the coefficient of variation was 37.84, considered high. This can be explained by the quantitative nature of the characteristic under study, which shows polygenic control (TCHIAGAM et al., 2011) and proves to be greatly influenced by the environment, whose effect showed a high level of significance in the present study.

When comparing the mean values of the genotypes for total protein content (TPC) using the mean-value test, separation into two distinct groups can be seen in both environments (Table 1). For the environment of Pentecoste, the MNC00-303-09E, Semper Verde, BRS Tumucumaque, BRS Guariba, Azulão and MNC00-595F-2 genotypes were highlighted, presenting values between $5.05 \%$ and $6.60 \%$ protein. In Acaraú, the Paulistinha, MNC05-835B-16, 
BRS Xiquexique, MNC00-595F-2, MNC99-541F-15, BRS Guariba and Azulão genotypes stood out, with values between $11.69 \%$ and $15.15 \%$. Note that some genotypes are found in the best group of both environments: MNC00-595F-2, BRS Guariba and Azulão.

The difference seen between genotypes, both in the same environment and between different environments, reveals the presence of genetic variability and, particularly, the effect of the environment, in addition to the GxE interaction. Giami (2005), verifying the composition of the cowpea, states that the chemical properties vary considerably according to the cultivar. Gonçalvez et al. (2020) and Teka et al. (2020), also reported a great variation in the amount and types of proteins found in different cowpea genotypes.

The CVg to CVe ratio was less than one in Acaraú and Pentecoste, which shows the great influence of the environment. Similar values were obtained by Santos et al. (2014), for cowpea yield. Heritability for total protein content was 59.79 and 75.44 for the environments of Acaraú and Pentecoste respectively. These values show that it is possible to select genotypes with the best performance for TPC, especially in Pentecoste, where heritability was superior. Martos-Fuentes et al. (2017), also obtained values for heritability that ranged from 0.36 to 0.89 in different environments. The results corroborate those of the GxE interaction, for which there is difficulty in selecting broadly adapted genotypes, but which makes local selection possible. Gerrano et al. (2017), cite the importance of this parameter for efficient genotype selection in breeding programs.

Vasconcelos (2010) found protein levels ranging from $23.00 \%$ to $26.00 \%$ for dry grain in the cowpea. Carvalho et al. (2012), when evaluating the chemical composition of 33 cowpea genotypes grown in Teresina, in the state of Piauí, including BRS-Guariba, BRSTumucumaque, BRS-Xique-xique and Paulistinha also evaluated in this study, obtained protein values of $22.70 \%, 24.80 \%, 17.70 \%$ and $23.00 \%$ respectively. These values were higher than those obtained in the present study, which confirms the great influence of the environment on this characteristic.

Table 1 - Comparison of mean values and genetic parameters for total protein content (TPC) in sixteen cowpea genotypes in two environments

\begin{tabular}{lcc}
\hline Genotype & Acaraú \% & Pentecoste $\%$ \\
\hline MNC00-303-09E & $7.24 \mathrm{Ab}$ & $6.60 \mathrm{Aa}$ \\
MNC00-595F-2 & $12.86 \mathrm{Aa}$ & $5.05 \mathrm{Ba}$ \\
MNC00-595F-27 & $10.63 \mathrm{Ab}$ & $4.12 \mathrm{Bb}$ \\
MNC05-835B-15 & $9.44 \mathrm{Ab}$ & $3.91 \mathrm{Bb}$ \\
MNC05-835B-16 & $14.04 \mathrm{Aa}$ & $4.60 \mathrm{Bb}$ \\
MNC05-841B-49 & $9.86 \mathrm{Ab}$ & $4.73 \mathrm{Bb}$ \\
MNC05-847B-123 & $8.45 \mathrm{Ab}$ & $4.28 \mathrm{Bb}$ \\
MNC05-847B-126 & $9.41 \mathrm{Ab}$ & $3.36 \mathrm{Bb}$ \\
MNC99-541F-15 & $12.75 \mathrm{Aa}$ & $2.72 \mathrm{Bb}$ \\
BRS Guariba & $12.15 \mathrm{Aa}$ & $5.23 \mathrm{Ba}$ \\
BRS Tumucumaque & $10.90 \mathrm{Ab}$ & $6.14 \mathrm{Ba}$ \\
BRS Xiquexique & $13.47 \mathrm{Aa}$ & $4.29 \mathrm{Bb}$ \\
Paulistinha & $15.15 \mathrm{Aa}$ & $4.01 \mathrm{Bb}$ \\
Vagem Roxa-THE & $7.98 \mathrm{Ab}$ & $3.82 \mathrm{Bb}$ \\
Azulão & $11.69 \mathrm{Aa}$ & $5.46 \mathrm{Ba}$ \\
Sempre Verde & $8.90 \mathrm{Ab}$ & $6.27 \mathrm{Aa}$ \\
\hline Mean & 10.93 & 4.66 \\
\hline CVg (\%) & 16.64 & 20.05 \\
CVg/CVe & 0.61 & 0.88 \\
$\mathrm{~h}^{2}$ (\%) & 59.79 & 75.44 \\
\hline
\end{tabular}

Mean values followed by the same uppercase letter on a line and lowercase letter in a column do not differ by Scott-Knott test at $5 \%$ significance. CVg: coefficient of genetic variation; $\mathrm{CVg} / \mathrm{CVe}$ : ratio between the coefficient of genetic variation and coefficient of environmental variation; $\mathrm{h}^{2}$ (\%): broad-sense heritability 
Higher total values for protein content were seen in the environment of Acaraú, compared to that of Pentecoste. In the former, the mean value was $10.93 \%$ TPC, while in the latter, the mean value was $4.66 \%$ (Table 1 ). In Acaraú, each genotype was in the group having higher mean values, this was different in Pentecoste. Only two genotypes did not differ statistically for protein content between the environments (MNC00-303-09E and Azulão). Ddamulira et al. (2017), found three genotypes with a more stable protein content among the 28 evaluated in the three environments under test.

Various factors can be highlighted regarding the influence of the environment. In Pentecoste, the ground was fallow, while in Acaraú, the area had been continuously cultivated with various crops, including cowpea. Knowing the importance of associating crops with nitrogen-fixing organisms, and that these are found more in soils previously cultivated with the species (DA SILVA et al., 2012), earlier use of the soil may influence nitrogen absorption and the protein content of the beans. Despite the crop being well-adapted to environmental stress, such as water stress, salinity and high temperatures (DA SILVA et al., 2018), these factors, together with soil fertility, can also interfere in cowpea performance. Fertilisation and irrigation carried out following the recommendations for the crop minimise these effects.

Genotype interaction has also been observed in complex environments, where the environmental effect interfered in the position of the genotypes. This type of interaction makes it difficult to select stable, broadly adapted genotypes (TORRES et al., 2015). The GxE interaction was also reported for total protein content in the cowpea by Gerrano et al. (2019) and Raina et al. (2020).

Regarding the production components, one complementary factor for the difference in protein content in the environments is yield and the number of grains per pod. In the environment of Pentecoste, productivity was $1591.91 \mathrm{~kg} \mathrm{ha}^{-1}$ and in Acaraú, $1342.85 \mathrm{~kg} \mathrm{ha}^{-1}$. The lowest protein content was found in the environment with the highest yield of green grain, i.e. with the highest number of green grains per pod. De Freitas et al. (2016), working with green pods of the cowpea, also found a significant difference between genotypes and environments (planting times).

These results are similar to those presented by Rangel et al. (2007), in the cowpea, common bean and soya. Those authors found that the protein content was lower at the highest yields, a fact explained by the greater number of drains in the plant (grains per pod) in addition to the dilution factor, where the protein is distributed to each drain.

From the path analysis (Table 2), the coefficient of determination $\left(\mathrm{R}^{2}\right)$ and the residual effect show how much the explanatory variables determine the basic variable of total protein content. The coefficient of determination was 0.39 and 0.48 , and the residual effect was 0.78 and 0.71 in Acaraú and Pentecoste respectively.

The values for the coefficient of determination of $39.00 \%$ and $48.00 \%$ for the protein content of the grain are due to the effect of the variables under analysis, showing that the independent variables green-pod length (GPL), green-pod weight (GPW), green-pod-grain weight (GPGW), number of green-pod grains (NGPG), 100green-grain weight $(100 \mathrm{GW})$, green-grain index (GGI), green-pod yield (GPY) and green-grain yield (GGY) represent little variation in the primary characteristic TPC, as their value is less than $50.00 \%$.

The residual effect of 0.78 and 0.71 , higher than the direct effects of the variables under analysis, except for GPGW in Acaraú, explains how an increase in the other variables under study does not imply a relationship of cause and effect with these variables only. A high residual effect ( 0.73 ) indicates that other variables to be considered by the breeder for indirect selection are plausible.

Table 2 also shows the correlation coefficients for both environments. For the environment of Acaraú, it be seen that the total protein content is positively correlated with each characteristic, except green-pod yield and green-grain yield. The correlations obtained were green-pod length (0.30), green-pod weight $(0.28)$, green-pod-grain weight $(0.39)$, number of green pod grains $(0.25), 100$-green-grain weight $(0.32)$, green-grain index $(0.19)$, green-pod yield $(-0.17)$ and green-grain yield (-0.10).

The results for these correlation coefficients show that increases in the secondary characteristics reflect positively on the total protein content (primary characteristic), and negatively on green-pod and green-grain yield, i.e. in the environment of Acaraú, the higher the green-pod and greengrain yield, the lower the total protein content of the grain, despite the correlations being of low magnitude.

In Pentecoste, the characteristics green-pod length (0.19), green-pod weight $(0.51)$, green-pod-grain weight (0.06), 100-grain weight $(0.30)$, green-pod yield $(0.30)$ and green-grain yield $(0.19)$ showed a positive correlation with the total protein content. The green-grain index $(-0.53)$ and number of green-pod grains $(-0.34)$ showed a negative correlation with the TPC.

According to these results, the characteristics with the greatest effect on the total protein content in Acaraú were green-pod-grain weight and 100-green-grain weight. In Pentecoste, the characteristics with the greatest effect were the green-grain index and green-pod weight.

Cargnelutti Filho et al. (2011), report that genotype $\mathrm{x}$ environment interactions are expected in trials conducted in different locations, years and growing times, and that 
Table 2 - Estimation of the direct and indirect effects of the production components green-pod length (GPL), green-pod weight (GPW), green-pod-grain weight (GPGW), number of green-pod grains (NGPG), 100-green-grain weight (100GW), green-grain index (GGI), green-pod yield (GPY) and green-grain yield (GGY) on total protein content (TPC) in the environments of Acaraú and Pentecoste

\begin{tabular}{|c|c|c|}
\hline \multirow{2}{*}{ Characteristic } & \multicolumn{2}{|c|}{ Correlation estimates } \\
\hline & Acaraú & Pentecoste \\
\hline \multicolumn{3}{|l|}{ Green-pod length (GPL) } \\
\hline Direct effect on protein & -0.22 & -0.01 \\
\hline Indirect effect via GPW & -5.40 & 0.32 \\
\hline Indirect effect via GPGW & 15.58 & -0.08 \\
\hline Indirect effect via NGPG & -3.54 & -0.10 \\
\hline Indirect effect via $100 \mathrm{GW}$ & -6.48 & -0.05 \\
\hline Indirect effect via GGI & 0.45 & 0.02 \\
\hline Indirect effect via GPY & 0.04 & -0.00 \\
\hline Indirect effect via GGY & -0.13 & 0.08 \\
\hline Total & 0.30 & 0.19 \\
\hline \multicolumn{3}{|l|}{ Green-pod weight (GPW) } \\
\hline Direct effect on proteína & -6.23 & 0.65 \\
\hline Indirect effect via GPL & -0.19 & -0.00 \\
\hline Indirect effect via GPGW & 17.36 & -0.13 \\
\hline Indirect effect via NGPG & -2.56 & -0.02 \\
\hline Indirect effect via $100 \mathrm{GW}$ & -8.61 & 0.02 \\
\hline Indirect effect via GGI & 0.64 & 0.05 \\
\hline Indirect effect via GPY & 0.05 & -0.00 \\
\hline Indirect effect via GGY & -0.18 & -0.06 \\
\hline Total & 0.28 & 0.51 \\
\hline \multicolumn{3}{|c|}{ Green-pod-grain weight (GPGW) } \\
\hline Direct effect on proteína & 18.21 & -0.28 \\
\hline Indirect effect via GPL & -0.18 & -0.00 \\
\hline Indirect effect via GGW & -5.94 & 0.31 \\
\hline Indirect effect via GPGW & -2.78 & -0.06 \\
\hline Indirect effect via $100 \mathrm{GW}$ & -8.91 & 0.05 \\
\hline Indirect effect via GGI & 0.12 & -0.01 \\
\hline Indirect effect via GPY & 0.03 & -0.01 \\
\hline Indirect effect via GGY & -0.16 & 0.06 \\
\hline Total & 0.39 & 0.06 \\
\hline \multicolumn{3}{|c|}{ number of green-pod grains (NGPG) } \\
\hline Direct effect on proteína & -4.39 & -0.20 \\
\hline Indirect effect via GPL & -0.18 & -0.00 \\
\hline Indirect effect via GPW & -3.63 & 0.07 \\
\hline Indirect effect via GPGW & 11.56 & -0.09 \\
\hline Indirect effect via $100 \mathrm{GW}$ & -2.88 & -0.03 \\
\hline Indirect effect via GGI & -0.11 & -0.01 \\
\hline Indirect effect via GPY & 0.04 & 0.00 \\
\hline Indirect effect via GGY & -0.16 & -0.08 \\
\hline Total & 0.25 & -0.34 \\
\hline
\end{tabular}


Continuation table 2

\begin{tabular}{|c|c|c|}
\hline \multicolumn{3}{|l|}{ 100-grain weight $(100 \mathrm{GW})$} \\
\hline Direct effect on proteína & -9.63 & 0.07 \\
\hline Indirect effect via GPL & -0.15 & 0.01 \\
\hline Indirect effect via GPW & -5.58 & 0.21 \\
\hline Indirect effect via GPGW & 16.86 & -0.20 \\
\hline Indirect effect via NGPG & -1.31 & 0.08 \\
\hline Indirect effect via GGI & 0.21 & -0.01 \\
\hline Indirect effect via GPY & 0.02 & -0.00 \\
\hline Indirect effect via GGY & -0.10 & 0.14 \\
\hline Total & 0.32 & 0.30 \\
\hline \multicolumn{3}{|l|}{ green-grain index (GGI) } \\
\hline Direct effect on proteína & -1.81 & -0.07 \\
\hline Indirect effect via GPL & 0.05 & 0.00 \\
\hline Indirect effect via GPW & 2.19 & -0.50 \\
\hline Indirect effect via GPGW & -1.16 & -0.04 \\
\hline Indirect effect via NGPG & -0.27 & -0.03 \\
\hline Indirect effect via $100 \mathrm{GW}$ & 1.10 & 0.01 \\
\hline Indirect effect via GPY & -0.04 & -0.00 \\
\hline Indirect effect via GGY & 0.13 & 0.11 \\
\hline Total & 0.19 & -0.53 \\
\hline \multicolumn{3}{|l|}{ Green-pod yield (GPY) } \\
\hline Direct effect on proteína & 0.12 & -0.00 \\
\hline Indirect effect via GPL & -0.07 & -0.00 \\
\hline Indirect effect via GPW & -2.45 & 0.08 \\
\hline Indirect effect via GPGW & 5.35 & -0.06 \\
\hline Indirect effect via NGPG & -1.39 & 0.06 \\
\hline Indirect effect via $100 \mathrm{GW}$ & -1.88 & 0.03 \\
\hline Indirect effect via GGI & 0.69 & -0.06 \\
\hline Indirect effect via GGY & -0.54 & 0.30 \\
\hline Total & -0.17 & 0.35 \\
\hline \multicolumn{3}{|l|}{ Green-grain yield (GGY) } \\
\hline Direct effect on proteína & -0.63 & 0.31 \\
\hline Indirect effect via GPL & -0.04 & -0.00 \\
\hline Indirect effect via GPW & -1.79 & -0.12 \\
\hline Indirect effect via GPGW & 4.55 & -0.06 \\
\hline Indirect effect via NGPG & -1.14 & 0.05 \\
\hline Indirect effect via $100 \mathrm{GW}$ & -1.54 & 0.03 \\
\hline Indirect effect via GGI & 0.39 & -0.02 \\
\hline Indirect effect via GPY & 0.10 & -0.00 \\
\hline Total & -0.10 & 0.19 \\
\hline Coefficient of Determination $\left(\mathrm{R}^{2}\right)$ & 0.39 & 0.48 \\
\hline Residual Effect & 0.78 & 0.71 \\
\hline
\end{tabular}


the results of path analysis are influenced by these factors. According to Zilio et al. (2011), the responses found in path analysis indicate the need for genotypes to be assessed in different environments in order to understand how a given genotype responds, especially regarding morphological and agronomic characteristics, besides showing the compensatory effect of the components.

For the estimates of the direct and indirect effects of the main production components (GPL, GPW, GPGW, NGPG, 100GW, GGI, GPY and GGY) on the main variable (TPC), the greatest direct effects were observed for GPGW (18.21), $100 \mathrm{GW}$ (-9.63) and GPW (-6.23), showing a high correlation with TPC in the environment of Acaraú. These results prove that the characteristic GPGW can be used as a factor for direct selection for TPC, with emphasis on its magnitude in the correlation. In Pentecoste, GPW (0.65) and GGY (0.31) showed a higher correlation with TPC and can be used for direct selection in this environment.

The indirect effects were relatively small in both environments, with some exceptions, such as GPGW in Acaraú, which showed a positive indirect effect for all characteristics; this is explained by a high direct effect on the protein content. This result shows the feasibility of direct and indirect selection via GPGW for gains in the most important primary characteristic (TPC). In Pentecoste, indirect selection is also possible via some characteristics, with emphasis on GPW and GGY. Raina et al. (2020), reported an increase in protein content in the cowpea via indirect selection based on quantitative characteristics, while Lazaridi et al. (2017), found no significant relationships. As such, the genetic material used, and the environment of each study have a great influence on this characteristic. As evaluations in breeding programs are based mainly on phenotype (COSTA; MELO; MANO, 2019), for beans, associating easily measurable characteristics with the total protein content (TPC) is of great value.

For the 100-grain weight (100 GW), green-pod weight (GPW) and number of green-pod grains (NGPG), a direct effect of $-9.63,-6.23$ and -4.39 respectively can be seen for Acaraú. These results affect the total protein content of the grain. Green grain yield (GGY) also had a negative effect (-0.63) on this characteristic. Therefore, the more productive the genotype, the lower the TPC. Moura et al. (2012), also found a negative correlation between cowpea yield and the protein, zinc and iron content. According to Barroso Neto et al. (2017), as it is a quantitative characteristic with polygenic inheritance, a great variation in grain yield is expected which is greatly influenced by the environment. This may have contributed to the variation in TPC, as both are correlated.

For Acaraú, it can be seen that the indirect selection of genotypes for total protein content among the production components can assist in cowpea breeding programs, since some components show high magnitude. For the environment of Pentecoste, the effects were of lower magnitude, but still make indirect selection possible. Gonçalves et al. (2017) also identified differences in sign and magnitude in the path analysis when evaluating agronomic characteristics in the common bean, which shows the influence of the environment on genotype selection.

The discrepancy in responses in relation to the environments under evaluation, underlines the importance of carrying out these studies in more than one location, thereby avoiding mistakes in the selection process, which can hinder progress in plant breeding programs.

\section{CONCLUSIONS}

1. The protein content in green cowpea grain may vary due to the place of cultivation, the effect of the interaction between genotype and environment, and the genetic variability of the cultivars;

2. In Acaraú, selecting genotypes for the best protein content should be done via direct selection of the greenpod-grain weight, 100-grain weight and green-pod weight. In Pentecoste, it should be via indirect selection of the green-pod weight and green-grain yield.

\section{REFERENCES}

BARROSO NETO, A. M. et al. Genetic variability and selection of extra-early cowpea. Revista Caatinga, v. 30, n. 3, p. 698-707, 2017.

BELSLEY, D. A.; KUH, E.; WELCH, R. E. Regression diagnostics: identifying data and sources of colinearity. 1. ed. New York: J. Wiley, 1980. 292 p.

BRADFORD, M. M. A rapid and sensitive method for the quantifications of microgram quantities of protein utilizing the principle of protein-dye binding. Analitycal Biochemistry, v. 72 , p. $248-254,1976$.

CARGNELUTTI FILHO, A. et al. Número necessário de experimentos para a análise de trilha em feijão. Ciência Rural, v. 41, n. 4, p. 564-572, 2011.

CARVALHO, A. F. U. et al. Nutritional ranking of 30 Brazilian genotypes of cowpeas including determination of antioxidant capacity and vitamins. Journal of Food Composition and Analysis, v. 26, n. 1-2, p. 81-88, 2012.

COSTA, F. C. L.; MELO, M. F.; MANO, A. R. O. Path Analysis in Cowpea Reveals Protein Accumulation Dependency of Mineral Nutrients Accumulation. Journal of Experimental Agriculture International, v. 32, n. 5, p. 1-10, 2019. 
CRAVO, M. S.;VIÉGAS, I.J.M.;BRASIL,E.C. Recomendações de adubação e calagem para o Estado do Pará. 1. ed. Belém: Embrapa Amazônia Oriental, 2007. 34 p.

CRUZ, C. D. GENES - a software package for analysis in experimental statistics and quantitative genetics. Acta Scientiarum, v. 35, n. 3, p. 271-276, 2013.

DA SILVA, A. C. et al. Cowpea: A strategic legume species for food security and health. In: JIMÉNEZ-LÓPEZ, J. C.; CLEMENTE, A. Legume Seed Nutraceutical Research. 1. ed. London: IntechOpen, 2018, cap. 3, p 47-65.

DA SILVA, D. O. M. et al. Adaptability and stability parameters of total seed yield and protein content in cowpea ('Vigna unguiculata') genotypes subjected to semi-arid conditions. Australian Journal of Crop Science, v. 10, n. 8, p. 1164-1169, 2016.

DA SILVA, M. F. et al. Nodulação e eficiência da fixação do $\mathrm{N}_{2}$ em feijão-caupi por efeito da taxa do inóculo. Revista Brasileira de Ciência do Solo, v. 36, n. 5, p. 1418-1425, 2012.

DDAMULIRA, G. et al. Grain yield and protein content of Brazilian cowpea genotypes under diverse Ugandan environments. American Journal of Plant Sciences, v. 6, n. 13, p. 2074-2084, 2015.

DDAMULIRA, G. et al. Maturity, protein content and yield stability of cowpea in Uganda. South African Journal of Plant and Soil, v. 34, n. 4, p. 255-261, 2017.

DE FREITAS, T. G. G. et al. Green bean yield and path analysis in cowpea landraces. Revista Caatinga, v. 29, n. 4, p. 866-877, 2016.

FONSECA, M. R. et al. Teor e acúmulo de nutrientes por plantas de feijão caupi em função do fósforo e da saturação por bases. Revista Ciências Agrárias, v. 53, n. 2, p. 195-205, 2010.

FREIRE FILHO, F. R. et al. Melhoramento genético. In: FREIRE FILHO, F. R.; LIMA, J. A. de A.; RIBEIRO, V. Q. Feijão-caupi: Avanços tecnológicos. 1. ed. Brasília: EMBRAPA, 2005, cap. 1, p 29-75.

FUNDAÇÃO CEARENSE DE METEOROLOGIA E RECURSOS HÍDRICOS. Calendário de Chuvas no Estado do Ceará. Fortaleza: FUNCEME, 2020. Disponível em: http:// www5.funceme.br/app/calendario/produto/municipios/maxima/ diario. Acesso em: 14 set. 2020.

GERRANO, A. S. et al. Nutritional composition of immature pods in selected cowpea [Vigna unguiculata (L.) Walp.] genotypes in South Africa. Australian Journal of Crop Science, v. 11, n. 2, p. 134, 2017.

GERRANO,A. S. et al. Selection of cowpea genotypes based on grain mineral and total protein content. Acta Agriculturae Scandinavica, Section B - Soil \& Plant Science, v. 69, n. 2, p. 155-166, 2018.

GONÇALVES, D. L. et al. Genetic correlation and path analysis of common bean collected from Caceres Mato Grosso State, Brazil. Ciência Rural, v. 47, n. 8, 2017.

GONÇALVES, F. V. et al. Characterization of the development of cowpea cultivars and of the quantity and quality of proteins in their grains. Pesquisa Agropecuária Brasileira, v. 55, n. e00837, 2020.
INSTITUTO DE PESQUISA E ESTRATÉGIA ECONÔMICA DO CEARÁ. Ceará em mapas. Fortaleza: IPECE, 2020. Disponível em: http://www2.ipece.ce.gov.br/atlas/capitulo1/12/126.htm. Acesso em: 7 set. 2020.

LAZARIDI, E. et al. Diversity in cowpea (Vigna unguiculata (L.) Walp.) local populations from Greece. Genetic resources and crop evolution, v. 64, n. 7, p. 1529-1551, 2017.

LI, C. C. Path analysis: a primer. 3 ed. Pacific Grove: Boxwood Press, 1975. 347p.

MARTOS-FUENTES, M. et al. Genotype by environment interactions in cowpea (Vigna unguiculata L. Walp.) grown in the Iberian Peninsula. Crop and Pasture Science, v. 68, n. 11, p. 924-931, 2017.

MONTGOMERY, D. C.; PECK, E. A. Introduction to linear regression analysis. New York: J. Wiley, 1981. 504 p.

MOURA, J. O. et al. Path analysis of iron and zinc contents and others traits in cowpea. Crop Breeding and Applied Biotechnology, v. 12, n. 4, p. 245-252, 2012.

RAINA, A. et al. Characterization of Induced High Yielding Cowpea Mutant Lines Using Physiological, Biochemical and Molecular Markers. Scientific reports, v. 10, n. 1, p. 1-22, 2020.

RANGEL, M. A. S. et al. Efeito da interação genótipo x ambiente no rendimento de grãos e nos teores de proteína de cultivares de soja. Acta Sci. Agron, v. 29, n. 3, p. 351-354, 2007.

REYES-MORENO, C.; PAREDE-LÓPEZ, O. Hard-to Cook Phenomenon in common bean: a review. Critical Reviews in Food Science \& Nutrition, v. 33, n. 3, p. 227-286, 1993.

SANTOS, A. et al. Correlations and path analysis of yield components in cowpea. Crop Breeding and Applied Biotechnology, v. 14, n. 2, p. 82-87, 2014.

SILVA, S.M.; FREIRE FILHO, F.R. Proteínas de feijão-caupi (Vigna unguiculata L. Walp).: Caracterização e aplicação nutricional. Teresina, PI: Embrapa Meio-Norte, 1999. 20 p.

TCHIAGAM, L. B. N. et al. Genetic analysis of seed proteins contents in cowpea (Vigna unguiculata L. Walp.). African Journal of Biotechnology, v. 10, n. 16, p. 3077-3086, 2011.

TEKA, T A. et al. Protein fractions, in vitro protein digestibility and amino acid composition of select cowpea varieties grown in Ethiopia. Food Bioscience, v. 36, n. 2020, p. 1-9, 2020.

TORRES, F. E. et al. Interação genótipo x ambiente em genótipos de feijão-caupi semiprostrado via modelos mistos. Bragantia, v. 74, n. 3, p. 255-260, 2015.

VASCONCELOS, I. M. et al. Protein fractions, amino acid composition and antinutritional constituents of high-yielding cowpea cultivars. Journal of Food Composition and Analysis, v.23, p. 54-60, 2010.

WENG, Y. et al. Evaluation of Seed Protein Content in USDA Cowpea Germplasm. HortScience, v. 54, n. 5, p. 814-817, 2019.

ZILIO, M. et al. Contribuição dos componentes de rendimento na produtividade de genótipos crioulos de feijão (Phaseolus vulgaris L.). Revista Ciência Agronômica. Fortaleza, v. 42, n. 2, p. 429-438, abr-jun, 2011. 